\title{
Study on Several Issues Related to Accountants' Social Responsibilities
}

\author{
Huang Juan \\ Jiangxi College Of Foreign Studies
}

\begin{abstract}
In today's society, it is of important and longterm realistic significance to explore the root of accounting information distortion and seek effective means to deal with the information distortion. The purpose of this paper is to establish an evaluation system for accountants by defining their social responsibilities during the formation of accounting information so as to truly deal with the accountants' information distortion. Besides, the relationship between accountants and the society has also been analyzed. Laterally, accountants have a close relationship with the society since accounting information is a coefficient result by various organs of authority in the plural society, and meanwhile it also serves various social groups, that is, users of accounting information. Longitudinally, accountants are products of the society. They have been constantly developed and perfected with the development of society. On the other hand, accountants also have an active reaction on the social environment around them.
\end{abstract}

Keywords-accountant; society; accounting information distortion; accountants'social responsibilities

\section{INTRODUCTION}

The quality of accounting information affects the allocation of social resources as well as the fairness and efficiency of the overall national economy system. Regardless of national economic construction, enterprises' operation and decision-making or rational investment in security market, they are all related to accounting information. However, in recent years, accounting information distortion has become a universal and prominent problem in national economic life all over the world.

Since accountants have an increasingly closer relationship with the society, modern accountants should be responsible for both the owner and operator of the enterprises as well as our society. An enterprise's financial goal to maximize stockholder's equity should be unified with the maximum social responsibilities. In this paper, much emphasis has been given to the accountants' social responsibilities. By defining related accountants' social responsibilities during the formation of accounting information, we can analyze the main problems during their fulfillment of social responsibilities, that is, deliberate make-up of false accounting information. Then some countermeasures will be further proposed to effectively deal with the accounting information distortion.

\section{THE RELATIONSHIP BETWEEN ACCOUNTANTS AND THE MACRO ENVIRONMENT, SOCIETY.}

Accountant is affected by environment and should be conformed to the environment instead of independent from the environment. Meanwhile, environment has a decisive effect on accountant's ideas, principles, methods and procedures. In general, the macro environment can be further divided into three parts, which are economic environment, political and legal environment and scientific technological environment.

\section{Economic environment}

Regardless of from the development history of accountants, or from the concepts of Marxism that productivity is the motivation of social development and economic basis decides the superstructure, economic environment has made a dominant difference on the emergence and development of accountants.

\section{Political and legal environment}

Politics is everywhere is modern society, which affects various aspects of people's life. Both economy and laws are restricted by politics; and meanwhile politics also decides the accounting legal system and administration system to some extent. Under different political systems, government has a different demand for the allocation and management of economic resources.

\section{Scientific and technological environment}

Science and technology plays an important role in improving economic development, which has become an influential factor for modern society's progress and development with an increasingly deeper effect. The rapid development of science and technology, especially the information technology, has deeply affected the whole process of accounting information from input to processing, transmission and usage. Thus, accounting information can be shared and timely transmitted all over the world, and finally the social status of accountants have been elevated.

\section{PROBLEMS DURING ACCOUNTANTS' \\ FULFILLMENT OF SOCIAL RESPONSIBILITIES IN LISTED COMPANIES}

In China, listed companies are fulfilling accountants' social responsibilities under a special economic circumstance. Under such circumstance, related accountants in listed companies may try to avoid fulfilling their social responsibilities by getting rid of restrictions from laws and government. During their 
fulfillment of social responsibilities, they may produce false accounting information deliberately, mainly including the following problems.

\section{Inflated assets and profits by counterfeiting transactions \\ Falsification of transactions is the simplest and most direct way including counterfeiting transactions and making up economic business. The falsification of tradition facts involves falsification of sales objects and sales business; besides, a series of legal certificates also need to be falsified such as economic contract, bank bills, financial invoice and customs declaration forms and so on. Therefore, such kind of falsification not only breaks the law of accounting, but also goes against the some important economic laws and regulations such as Contract Law and Tax Law.}

\section{Manipulate profits by employing unfair related transactions}

Due to particular system and history, listed companies in our country has a complicated associated relationship with its parent company, other affiliated companies as well as associated companies. The purpose of associated transactions inside the Corporate Group is to reduce the transaction cost and improve the operation efficiency without involving capital market. However, if the associated transaction is related to capital market, it may become an important means for associated parties and listed companies to transfer their profits and capitals because of the relationship between commission and agency as well as disagreed equities among big stockholders and small stockholders.

\section{COUNTERMEASURES TO DEAL WITH THE PROBLEMS IN ACCOUNTANTS' FULFILLMENT OF SOCIAL RESPONSIBILITIES IN LISTED COMPANIES}

In China's listed companies, there have been inflated assets and profits by counterfeited transactions, manipulation of profits by unfair associated transactions, regulation of profits by improper accounting policies and compensation for financial loss with unusual earnings during accountants' fulfillment of social responsibilities. Although these problems have deep systematic circumstance, accountants' social responsibilities can't be exempted because of these reasons. The accountants' social responsibilities an be strengthened in the following ways.

\section{A. The external environment for related accountants fulfillment of social responsibilities can be improved.}

From the circumstance in listed companies for accountants' fulfillment of social responsibilities, we can see that the security market has immature system, unsound accounting laws and regulations, independent external audit and imperfect treatment structure, which has affected related accountants' fulfillment of social responsibilities without any restriction.

\section{Enhance the legislation and law-enforcement for} accountants social responsibilities

By perfecting the Company Law, Security Transaction Law and Accounting Law, accountants' social responsibilities can be defined with emphasis on the protection of social interest as well as deserved legal responsibilities. Meanwhile, accountants and related staff can establish legal awareness of social responsibilities by strictly executing rigid restrictions. In addition, related social interest groups can be guided to actively participate in the formulation of accounting system so as to form a complete competitive accounting mechanism.

\section{Strengthen accountants and related staffs moral- discipline}

The accountants and related personnel refer to accounting personnel in a broad sense, including director of a unit, administrator of financial affairs, accountants, registered accountants and so on. Accounting is the core of accountants' social responsibilities, which is closely related to accountants' moral self-control and introspection to most extent.

\section{CONCLUSION}

To sum up, since accountants have had an increasingly closer relationship with the society, their social responsibilities are becoming greater, so they should fulfill the social responsibilities actively. If accountants and related personnel can fulfill their duties actively, they will make great contributions to the social development. On contrary, it will bring many problems, and one of the most serious problems is accounting information distortion.

At present, the external environment for accountants' fulfillment of social responsibilities is very special, which requires them to undertake the duties actively. In the paper, countermeasures have been proposed to improve the external environment so as to enhance the accountants' social responsibilities, strengthen the legislation and law-enforcement of accountants' social responsibilities as well as accountants' moral self-discipline.

\section{REFERENCES}

[1] Ball R, Brown P. An Empirical Evaluation of Accounting Income Numbers[J]. Journal of Accounting Research, 1968, 6(2):159-178.

[2] Thaler R. Mental Accounting and Consumer Choice[J]. Marketing Science, 1985, 27(1):15-25.

[3] Thaler R. Mental Accounting and Consumer Choice[J]. Marketing Science, 1985, 27(1):15-25

[4] Bagozzi R P, Silk A J. Mental Accounting and Consumer Choice[J]. Marketingence, 1985, 27(1):15-25.

[5] Healy P M. The effect of bonus schemes on accounting decisions $\checkmark[\mathrm{J}]$. Journal of Accounting \& Economics, 1985, 7(85):85-107.

[6] Wackernagel M, Onisto L, Bello P, et al. National natural capital accounting with the ecological footprint concept[J]. Ecological Economics, 1999, 29(3):375-390.

[7] Dechow P M. Accounting earnings and cash flows as measures of firm performance : the role of accounting accruals[M]// University Microfilms International, 1992:3-42.

[8] Feltham G A, Ohlson J A. Valuation and Clean Surplus Accounting for Operating and Financial Activities[J]. Contemporary Accounting Research, 1995, 11(2):689-731. 
[9] Kothari S P. Capital markets research in accounting[J]. Journal of Accounting \& Economics, 2001, 31(01):105-231.

[10] Johnson H T, Kaplan R S. The Rise and Fall of Management Accounting[J]. Engineering Management Review IEEE, 1987, 15(3):3644.
[11] Fan J P H, Wong T J. Corporate ownership structure and the informativeness of accounting earnings in East Asia[J]. Journal of Accounting \& Economics, 2002, 33(02):401-425.

[12] Chatman J A. Matching people and organizations : selection and socialization in public accounting firms[M]// U.M.I., 1989:459-484 